\title{
Tick loads in Bos taurus cattle grazing in two contrasting production systems
}

\author{
Carga de garrapatas en bovinos Bos taurus que pastorean en dos \\ sistemas productivos contrastantes
}

Raquel Salazar B, ${ }^{1,2}$ MV, Rolando Barahona-Rosales, ${ }^{1 *}$ Ph.D, María-Solange Sánchez P, ${ }^{3}$ Ph.D.

\begin{abstract}
1 Universidad Nacional de Colombia, Facultad de Ciencias Agrarias, Departamento de Producción Animal, Sede Medellín, ${ }^{2}$ Centro para la Investigación en Sistemas Sostenibles de Producción Agropecuaria - CIPAV. ${ }^{3}$ Compañía Nacional de Chocolates, Grupo NUTRESA, Rionegro, Antioquia. *Correspondencia: rbarahonar@unal.edu.co
\end{abstract}

Received: March 2015; Accepted: December 2015.

\begin{abstract}
Objectives. To relate the effect of biotic and abiotic factors on Rhipicephalus (Boophilus) microplus tick loads on cows grazing either in intensive silvopastoral systems (ISS) (Lucerna) or in grass pastures associated with sugarcane plantations (La Isabela). Materials and methods. Tick counts were performed on 27 Lucerne breed animals that were in different physiological states, six of which were grazing on forage grass paddocks associated with commercial sugarcane plantations and the remaining animals grazed in an ISS based on Leucaena leucocephala and Cynodon plectostachyus. The tick counts were made every 15 days. The data of temperature, humidity, and radiation were taken from a weather station that was inside the ISS. Results. There was a weak relationship between saturation deficit and tick load $\left(R^{2}=0.34\right)$ and another between UV radiation and tick load $\left(R^{2}=0.205\right)$ for animals grazing in ISS. There were differences in tick counts when comparing animals of similar productivity from both systems evaluated: in La Isabela (sugarcane grass paddocks) average counts were 311 ticks perceptible to the touch (TPT) and in Lucerna (ISS farm) average counts were 206 TPT $(p=0.02)$. Additionally, there were greater tick counts in high productivity cows compared to low productivity cows. Conclusions. The abiotic and biotic factors of the ecosystem and animal productivity can affect the TPT counts. In ISS systems, tick counts can be lower than those observed in monoculture grazing systems.
\end{abstract}

Key words: Ectoparasites, microclimate, radiation, saturation deficit (Source: $C A B$ ).

\section{RESUMEN}

Objetivos. Relacionar el efecto de algunos factores bioticos y abioticos sobre las cargas de la garrapata Rhipicephalus (Boophilus) microplus en hembras bovinas que pastorean en sistemas silvopastoriles intensivos (SSPi)(Lucerna) y en monocultivos asociados a cañaduzales (La Isabela). Materiales y métodos. Se realizaron conteos en 27 animales de raza Lucerna en diferentes estados fisiológicos, seis de los cuales se encontraban pastoreando en lotes de gramíneas forrajeras asociados con plantaciones de caña comerciales y los animales restantes pastoreaban en SSPi basados en Leucaena leucocephala y Cynodon plectostachyus. El conteo de garrapatas se efectuó cada 15 días. Los datos de temperatura, humedad y radiación se tomaron de una estación meteorológica que se encontraba en el interior del SSPi. Resultados. Se encontró una relación débil entre el déficit de saturación y los conteos de garrapatas $\left(R^{2}=0.34\right)$ y entre la radiación UV y los conteos de garrapatas $\left(R^{2}=0.205\right)$ 
para los bovinos pastoreando en SSPi. Hubo diferencia entre los conteos en animales con similar productividad en ambos sistemas evaluados; siendo el promedio total de garrapatas perceptibles al tacto (GPT) de 311 para La Isabela y de 206 GPT para Lucerna $(p=0.02)$. Hubo mayor número de GPT en hembras con mayor productividad en comparación con las de baja productividad $(p<0.05)$. Conclusiones. Los factores bióticos y abióticos del ecosistema pueden influir en el promedio de GPT, al igual que el nivel de productividad de los animales. En SSPi, la carga de garrapatas puede ser inferior a la de sistemas de pastoreo en monocultivo.

Palabras clave: Ecosistemas, ectoparásitos, microclima, radiación (Fuente: $C A B$ ).

\section{INTRODUCTION}

The presence of ticks on livestock farms is a global concern, given the economic and production losses that are associated with their presence in the beef and dairy industries, which amount to millions of dollars worldwide (1). These losses are due to the decrease in milk or meat production and increases in production costs associated with the control of ticks and the application of pharmaceuticals for the treatment of tick-borne diseases (2).

Ticks are poikilothermic parasites that depend on ambient temperature for their activities, with the minimum thermal threshold being $14^{\circ} \mathrm{C}(3)$ and optimum physiological development occurring between 27 and $32^{\circ} \mathrm{C}$ (4). Thus, tick growth is strongly temperature dependent, and when their need to engage in physiological adaptation activities is reduced, their reproductive ability increases. Other variables that strongly affect the survival of these populations is humidity and solar radiation by its effect on the drying of larvae and eggs $(3,5,6)$. With increasing global temperatures predicted as part of climate change, it is expected that these arachnids are favored and can colonize new areas of life (5). The establishment of populations in new ecological zones will transfer the problems to new farmer, resulting in decreased production and increased production costs associated with tick control and treatment of blood parasites, in addition to the possible death of livestock.

The impact of abiotic factors may vary depending on the type of habitat, as a temperature of $28^{\circ} \mathrm{C}$ does not generate the same effect in a system with trees than in one without trees (3). This is an important consideration for intensive silvopastoral systems (ISS), production systems that promote inclusion of shrubs and trees in high densities and that have shown improvements in productivity $(7,8)$, efficiency in use of feed resources (9) and animal welfare (10).

In an ISS, the presence of shrubs and trees in the pasture can lead to an alteration in the rate

\section{INTRODUCCIÓN}

La presencia de garrapatas en las unidades de producción ganaderas es una preocupación mundial debido a las pérdidas económicas y productivas que generan tanto en las industrias cárnicas y lácteas. Dicho daño asciende a millones de dólares a nivel mundial (1). Estas pérdidas obedecen a la disminución en la producción láctea o cárnica y al aumento en los costos de producción asociados al control de garrapatas y la aplicación de farmacéuticos usados en el tratamiento de las enfermedades transmitidas por las garrapatas (2).

Las garrapatas son parásitos poiquilotermos, que dependen de la temperatura ambiental para sus actividades, siendo $14^{\circ} \mathrm{C}$ (3) el umbral térmico mínimo y entre 27 y $32^{\circ} \mathrm{C}$ (4) el óptimo para su desarrollo fisiológico. Así, el aumento de esta población depende fuertemente de la temperatura, ya que al disminuir la necesidad del arácnido para dedicarse a actividades fisiológicas de adaptación, aumenta su capacidad de procreación. Otras variables que inciden fuertemente en la sobrevivencia de estas poblaciones es la humedad ambiental y la radiación solar por su efecto sobre la desecación de larvas y huevos $(3,5,6)$. Con el aumento de la temperatura mundial pronosticado como parte del cambio climático, es de esperar que estos arácnidos se vean favorecidos y puedan colonizar nuevas zonas de vida (5). El establecimiento de poblaciones en nuevas zonas de vida trasladará los problemas a nuevas unidades de producción, resultando en una disminución en la producción y un aumento en el costo de producción asociado a gastos de control de garrapatas y tratamiento de hemoparásitos, además, de las posibles muertes de los semovientes.

El impacto de los factores abióticos puede variar dependiendo del tipo de hábitat, ya que no se genera el mismo efecto sobre los seres vivos a temperatura de $28^{\circ} \mathrm{C}$ en un sistema con árboles que en uno sin árboles. (3). Esta es una consideración importante para los sistemas silvopastoriles intensivos (SSPi), que promueven la inclusión de arbustos y árboles a grandes densidades con aumentos en productividad $(7,8)$, 
of development of Rhipicephalus (Boophilus) microplus ticks due to a variation in microclimate. Therefore, this study aimed to identify the influence of some biotic and abiotic factors on the number of tick $R$. (B.) microplus on cattle ISS and monoculture grassland systems located in the Valle del Cauca, Colombia.

\section{MATERIALS AND METHODS}

Description of the farms. The study took place in two farms located in Bugalagrande, Valle del Cauca, a site classified as tropical dry forest with $1100 \mathrm{~mm}$ average annual precipitation (Table 1). Both farms have milk production systems with cattle of the Lucerna breed, Colombian creole cattle generated after a series of crosses of Bos taurus cattle (Table 1). In La Isabela farm, animals grazed on the grass strips associated with sugarcane crops. In turn, the Lucerna farm is a dairy farm with 63 hectares in silvopastoral systems, comprised of the grasses star grass (Cynodon nlemfluensis) and guinea (Megathyrsus maximus) and the legumes leucaena (Leucaena leucocephala) and gliricidia (Gliricidia sepium). The Lucerna farm is also a producer of organic cane, for which allocates 160 hectares which surround the pastures for cattle grazing. In both farms, the same type of livestock is used; the Lucerna breed, which is a Colombian native cattle resulting from a series of crosses of Bos taurus breeds.

Animal selection. The selection criteria for experimental animals included choosing animals of recent entry into the different production groups, to ensure their prolonged residence time in the study. For any given group, the same number of individuals was selected. At Hacienda Lucerna, four groups were formed in total: Recently calved (RC), production group one (P1), production group two (P2) and dry cows (Dry). In this farm, and despite the initial selection, en la eficiencia de uso de recursos alimenticios (9) y en el bienestar animal (10).

En un SSPi, la presencia de arbustos y árboles en el potrero puede conducir a una alteración en la tasa de desarrollo de la garrapata Rhipicephalus (Boophilus) microplus debido a una variación en el microclima. En consecuencia, el presente estudio tuvo como propósito identificar la influencia de algunos factores bióticos y abióticos sobre el número de garrapata $R$. (B.) microplus sobre bovinos en SSPi y en sistemas de praderas en monocultivo ubicados en el Valle del Cauca.

\section{MATERIALES Y MÉTODOS}

Descripción de las fincas. El estudio se realizó en dos unidades de producción pecuaria (UPP) situadas en Bugalagrande, Valle del Cauca, clasificado según Holdridge como Bosque seco tropical con $1100 \mathrm{~mm}$ de precipitación promedio anual (Tabla 1). Ambas fincas poseen sistemas de produccion de leche con ganado de la raza Lucerna, ganado criollo colombiano resultado de una serie de cruces de ganado Bos taurus. (Tabla 1). Los animales pertenecientes a La Isabela, pastoreaban las franjas de gramíneas asociadas a los cultivos de caña. El ganado Lucerna, cuenta con 63 hectáreas destinadas a la ganadería en sistemas silvopastoriles, conformados por estrella (Cynodon nlemfluensis) y guinea (Megathyrsus maximus) y las leguminosas leucaena (Leucaena leucocephala) y matarratón (Gliricidia sepium).

Selección de animales. El criterio para seleccionar los individuos se basó en incluir animales de reciente ingreso a cada grupo de producción, con el fin de asegurar un mayor tiempo de permanencia. Se eligió igual número de individuos para cada grupo. En Lucerna se conformaron en total cuatro grupos: Recién paridas (RP), producción uno (P1), producción dos (P2) y vacas secas (Secas). Pese a la selección

Table 1. Characteristics of the farms and animals selected for the study.

\begin{tabular}{|c|c|c|c|c|c|}
\hline \multirow[b]{2}{*}{ Details } & \multicolumn{4}{|c|}{ Hacienda Lucerna } & \multirow[b]{2}{*}{ La Isabela } \\
\hline & $\begin{array}{l}\text { Recently calved } \\
\text { (RC) }\end{array}$ & Lactating (P1) & Lactating (P2) & Dry cows & \\
\hline System type & Silvopastoral & Silvopastoral & Silvopastoral & Silvopastoral & $\begin{array}{l}\text { Grazing grass in the alleys of } \\
\text { sugarcane plantations }\end{array}$ \\
\hline Type of milking & Mechanical & Mechanical & By hand & ---- & By hand \\
\hline $\begin{array}{l}\text { Total number of animals } \\
\text { per group }\end{array}$ & 13 & 15 & 6 & 17 & 6 \\
\hline Supplementation & $\begin{array}{l}\text { Concentrate, } \\
\text { byproducts }\end{array}$ & $\begin{array}{l}\text { Concentrate, } \\
\text { byproducts }\end{array}$ & $\begin{array}{l}\text { Concentrate, } \\
\text { byproducts }\end{array}$ & No supplement & Concentrate, byproducts \\
\hline Milk production & 11.57 & 8.93 & 8.85 & Out of production & 8 \\
\hline
\end{tabular}


the movement of individuals within groups did not allow maintaining uniform animal group numbers throughout the study. In La Isabela, the permanence of animals within the group was favored by management, as individuals grazed in one single group regardless of productivity.

Tick counts. Tick counts were performed every fifteen days following the methodology of Wharton and Utech (11). In this technique, only the left side of the animal is used to perform the count, only counting ticks perceptible to the touch $(>4 \mathrm{~mm})$. For greater uniformity, the animal's body was divided into eight regions in order to reduce counting errors. These regions were: loin, ribs, abdomen, forelimb, hind limb, perianal area, armpit and udder. Tick counts were performed every fortnight in collaboration with the staff of the farm.

Calculation of forage biomass availability. Quantification of fodder availability from the ISS was performed according to the double sampling method (12). A modification of the same method was used to quantify biomass from Leucaena. In short, three one-meter rows representing different levels of growth of Leucaena (high, medium, low) were defined, fodder (leaves and fine stems) was harvested and weighed. Using this scale, at least 50 one-meter rows were visually scored.

Climatic data. Climatic data were obtained from a meteorological station installed inside the Hacienda Lucerna ISS in a shade-free site and any other component that could affect the measurements. The following variables were measured: temperature, humidity and radiation. Precipitation data were obtained from three rain gauges located in different sites of the hacienda. In the case of Hacienda La Isabela, the climatic data obtained from the Lucerna farm meteorological station was used, given the proximity of both farms.

The saturation deficit was calculated from relative humidity and temperature data. The formula used to calculate the saturation deficit is:

$D_{a}=q_{a} *\left(T_{s}\right)-q_{a}$

Where $\mathrm{q}_{\mathrm{a}}=$ Real absolute humidity and $\mathrm{T}_{\mathrm{s}}=$ dry bulb temperature

Data for saturation deficit and UV index were obtained from an average of 12 days before the counting day. The number of days was selected after a previous study of the life cycle of the tick $R$ (B) microplus about the time required by ticks to reach the size to be perceptible to the touch $(4 \mathrm{~mm})$. inicial, los grupos presentaron movimientos de individuos impidiendo mantener el mismo número de animales dentro de los grupos durante todo el estudio.

Conteo de garrapatas. El conteo quincenal se realizó de acuerdo a la técnica sugerida por Wharton y Utech (11). En esta técnica, se usa únicamente el lado izquierdo del animal, contando solamente las garrapatas perceptibles al tacto $(>4 \mathrm{~mm})$. Para mayor uniformidad en el proceso de conteo, el cuerpo del animal se dividió en ocho regiones con el fin de disminuir los errores de conteo. Estas regiones fueron: Lomo, costillas, abdomen, miembro anterior, miembro posterior, área perianal, axila y ubre. Los animales fueron separados luego del ordeño, identificándolos por el número del anca y permanecieron en el corral aproximadamente dos horas. Los conteos se realizaron cada quince días con colaboración de personal de la finca.

Cálculo de la producción total de biomasa. La cuantificación de la oferta de gramíneas presentes en el SSPi se realizó de acuerdo al método de doble muestreo (12). En la cuantificación de la biomasa proveniente de Leucaena se utilizó una modificación del mismo método, inicialmente concebido para determinar la oferta forrajera de gramíneas. En el caso de Leucaena, se definieron tres estratos de un metro lineal que representaron diferentes niveles de crecimiento de Leucaena (alto, medio, bajo). Para cada estrato se cosechó y pesó el material (hojas y tallos finos). Usando esta escala, se calificaron al menos 50 visuales; del mismo modo que para las gramíneas, estimándose la disponibilidad de forraje total de cada franja.

Datos climáticos. Los datos climáticos fueron obtenidos de una estación meteorológica instalada al interior del SSPi de Lucerna, en un sitio libre de sombra y de cualquier otro componente biótico o abiótico que pudiera generar alteraciones en las mediciones. Se midieron las siguientes variables: Temperatura, humedad y radiación. Los datos de precipitación fueron tomados de tres pluviómetros, ubicados en sitios diferentes de la hacienda. En el caso de la Hacienda La Isabela, se interpolaron los resultados obtenidos de la estación ubicada en Lucerna, dada la cercanía de ambas fincas.

El déficit de saturación es calculado con los datos de humedad relativa y la temperatura obtenidos de la estación meteorológica. Los resultados obtenidos de este cálculo fueron promediados. La fórmula para calcular el déficit de saturación es:

$D_{a}=q_{a} *\left(T_{s}\right)-q_{a}$

Donde, $\mathrm{q}_{\mathrm{a}}$ : Humedad absoluta real $\mathrm{y} \mathrm{T}_{\mathrm{s}}$ : Temperatura del bulbo seco 
Ethical aspects. This study had no implicit practices that were detrimental to the welfare of animals. Ticks counts were made in the milking pen, making sure of providing stress-free conditions for all animals. The person in charge of such counts was veterinarian, which also ensured adequate monitoring of the animal conditions.

Data Analysis. Tick loads of different groups were analyzed by analysis of variance following a completely randomized design. Duncan's test was used for separation of the production groups means. Additionally, correlation analyses between animal tick load data and climatic variables were performed, including those with the UV index and saturation deficit calculated before tick counts.

\section{RESULTS}

Parasitic loads of $R$. (B.) microplus in different production groups.Throughout the study, there was variability in parasite counts among the groups evaluated, which was associated with the production group.

When calculating the count in Hacienda Lucerna, differences $(p<0.05)$ between the RC, P1 and dry cows groups. The group of hand milking behaved atypically (Figure 1). On average, animals with greater nutritional requirements had higher counts.

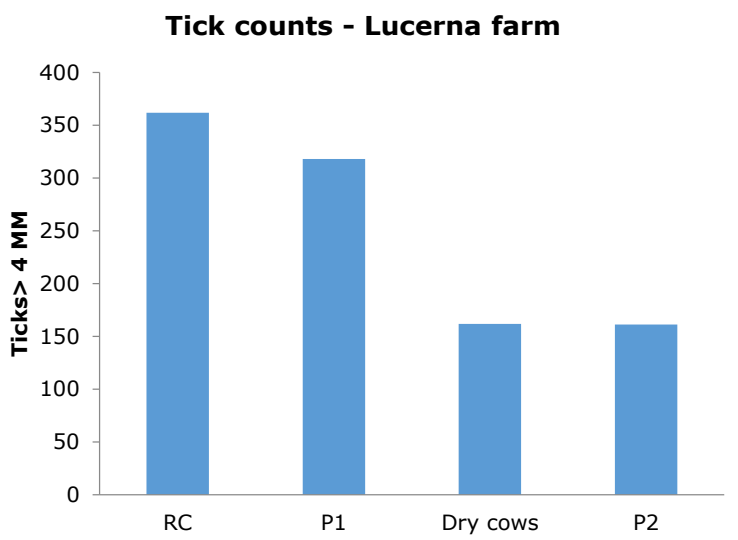

Figure 1. Average tick loads (ticks greater than $4 \mathrm{~mm}$ ) in Lucerna cattle from the four study groups at Hacienda Lucerna, Bugalagrande, Valle del Cauca.

To compare the two farms, animal groups of similar characteristics in terms of production were chosen, and that meant averaging P1 and P2 counts for Lucerna and compare this average with the group average of La Isabela (Figure 2). This analysis showed statistical difference in the average counts for both farms $(p=0.043)$.
Los datos correspondientes a déficit de saturación e índice UV fueron obtenidos de un promedio de 12 días previos incluyendo el día del conteo. El número de días fue seleccionado luego de un estudio previo del ciclo biológico de la garrapata $R$. (B.) microplus acerca del tiempo de permanencia sobre el hospedado antes de alcanzar el tamaño para ser perceptible al tacto $(4 \mathrm{~mm})$.

Aspectos éticos. En este estudio no incurrió en prácticas que fueran en detrimento del bienestar de los animales. Los conteos se realizaron en el corral, asegurándose de proporcionar condiciones libres de estrés para todos los animales. La persona encargada de dichos conteos era Médico Veterinario, lo que aseguró además, un monitoreo adecuado de la condición de estos.

Análisis de datos. Las cargas parasitarias de los diferentes grupos fueron analizados mediante un análisis de varianza siguiendo un diseño totalmente al azar. Se usó la prueba de Duncan para separación de medias de los grupos de producción. Adicionalmente, se realizaron análisis de correlación entre los datos de carga parasitaria de los animales con los datos de las variables climáticas, incluyendo el índice UV y el déficit de saturación calculados días previos al conteo.

\section{RESULTADOS}

Cargas parasitarias de $R_{\text {. (B.) microplus en }}$ diferentes grupos de producción. A lo largo del estudio, hubo variabilidad en la carga parasitaria de los individuo, la cual estuvo relacionada, con el grupo de producción.

Al calcular el conteo en Lucerna se encontraron diferencias $(p<0.05)$ entre los grupos RP, P1 y vacas secas. El grupo de ordeño a mano se comportó de forma atipica. (Figura 1). Los animales con los mayores requerimientos nutricionales tuvieron en promedio los mayores conteos.

Para la comparación entre las dos fincas, se buscaron grupos que tuvieran características similares en cuanto a producción, para lo que promediaron los conteos de los grupos P1 y P2 pertenecientes a Lucerna y se comparó con el promedio grupal de La Isabela (Figura 2). Este análisis mostró diferencia estadística en los conteos promedio de ambas fincas $(p=0.043)$

Relación entre algunos factores abióticos y

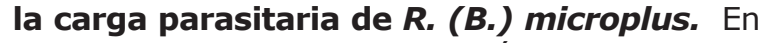
La Isabela, hubo una correlación positiva entre el acumulado de lluvia mensual y las cargas parasitarias de $R$. (B.) microplus mayores a $4 \mathrm{~mm}$ $\left(R^{2}=0,53\right.$; Figura 3$)$ 


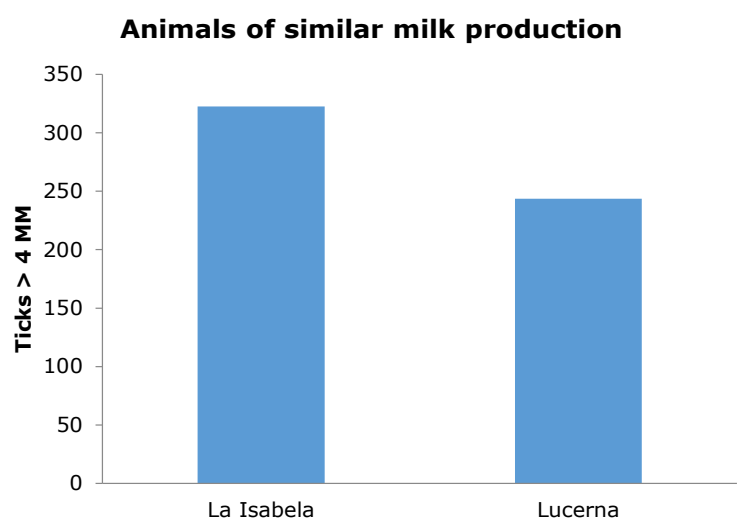

Figure 2. Average tick loads (ticks greater than $4 \mathrm{~mm}$ ) in Lucerna cattle grazing in Hacienda Lucerna and La Isabelita, Bugalagrande, Valle del Cauca.

Relationship between some abiotic factors and parasite load of $R_{\text {. (B.) microplus. }}$ At Hacienda La Isabela, there was a positive correlation between cumulative monthly rainfall and tick counts $\left(R^{2}=0.53\right.$; Figure 3$)$.

UV radiation is negatively related to the average total parasite load in the Lucerna animals $\left(R^{2}=0.205\right)$. Although weak, this trend suggests an increase in parasite load in the days that had low UV index values (Figure 4). The UV index appears to be an opposite variable to the saturation deficit, since increased saturation deficit was associated with increased counts $\left(\mathrm{R}^{2}=0.34\right.$; Figure 5).

Relationship between forage supply and the frequency of acaricide baths. Figure 6 shows the availability of biomass as determined

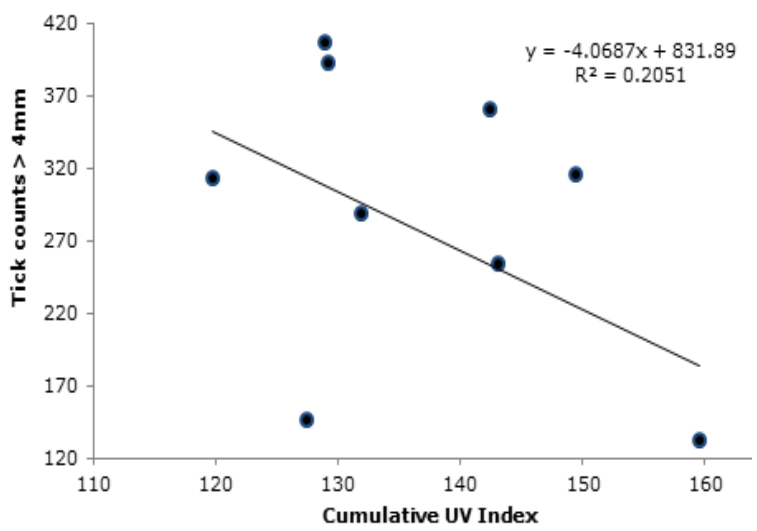

Figure 4. Relationship of cumulative UV index during the 12 days prior to the counts with the average tick loads in Lucerna cattle grazing in a silvopastoral system, Hacienda Lucerna, Bugalagrande, Valle del Cauca.

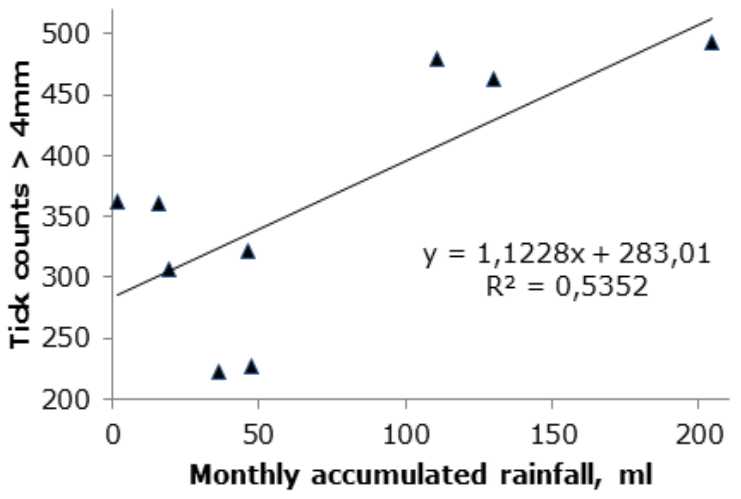

Figure 3. Monthly-accumulated rainfall and its relation to tick $R(B)$ microplus loads on cattle Bos Taurus grazing on grass strips associated with sugarcane plantations, Finca La Isabela, Bugalagrande, Valle del Cauca.

La radiación UV se relacionó negativamente con el promedio total de la carga parasitaria de los animales de Lucerna $\left(R^{2}=0,205\right)$. Aunque débil, esta tendencia insinúa un aumento en la carga parasitaria en los días que presentaron bajos valores del índice UV (Figura 4). El índice UV parece ser una variable opuesta al déficit de saturación, ya que, la relación sugiere con un $\mathrm{R}^{2}=0.34$ que un aumento del déficit de saturación se relacionó con un aumento de los conteos (Figura 5).

Relación entre la oferta de forraje y la frecuencia de baños acaricidas. En la figura 6 se muestra la disponibilidad de biomasa en los SSPi la cual fue medida por medio de aforos realizados durante ocho meses, tanto para leucaena como para estrella, además, del número de baños acaricidas que se realizaron en la finca durante esos mismos meses. En Lucerna, la decisión es manejar al mínimo los baños acaricidas. La carga parasitaria

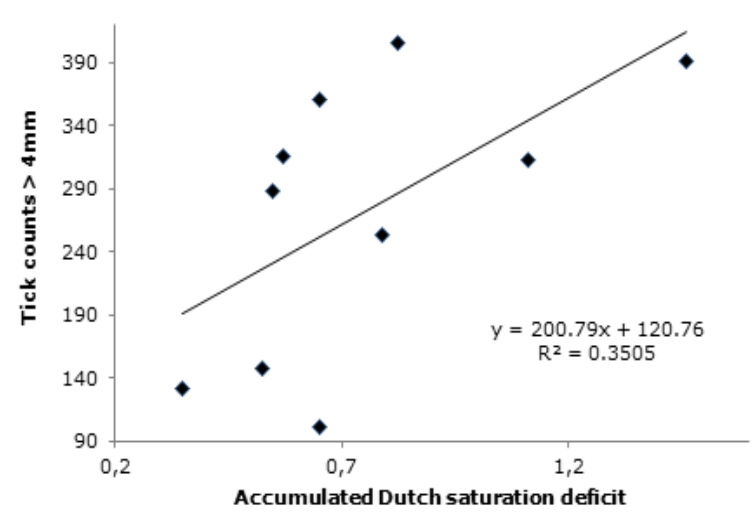

Figure 5. Relationship of accumulated Dutch saturation deficit during the 12 days prior to the counts with the average tick loads in Lucerna cattle grazing in a silvopastoral system, Hacienda Lucerna, Bugalagrande, Valle del Cauca. 
by the appraisals made in ISS for eight months. Biomass availability is shown separately for leucaena and star grass, as well as the number of acaricide baths that were carried out in the same period. At Hacienda Lucerna, the decision is to carry out the minimum possible of acaricide baths. The parasite load decreased $74.5 \%$ by the end of October and $38.8 \%$ after the bath made in December.

\section{DISCUSSION}

The tick R. B. microplus generates great economic losses in livestock production, which are related to weight loss and reduced milk production, infections, blood parasites in infected animals and increased costs of acaricide baths. Negative effects can vary between animals due to the possible existence of acquired and natural resistance. In turn, the resistance depends on the animal breed, its physiological and health status (13). The greatest economic loss is associated to the reduction of milk production, reproductive problems and animal mortality. Additionally, there are indirect losses associated to the treatments used to control blood parasites and synthetic baths for tick control (14).

Parasitic loads of R. (B.) microplus in different production groups. The results of this study are similar to those reported by Salazar et al (2), in a study carried out in the municipality of Piedras, Tolima in which lower tick loads were observed in Bos indicus x Bos taurus animals grazing in an ISS as compared with monoculture pastures systems. Both studies evaluated production systems under similar climatic conditions, which corroborates the observation that in ISS, tick loads are reduced. By contrast, Navas (14), reported that the number of larvae found in soil in paddocks with trees had no differences with those found in a pasture without trees. It is likely that differences between studies were due to differences in the arrangements of the systems evaluated, since the density of shrubs and trees in the pasture can generate a change in the ecosystem and affect the life cycle of the organisms that inhabit it.

In the animals of this study, much greater (at least 5x) tick counts were observed than those observed in the Hacienda el Chaco by Salazar et al (2). This could be due to differences in management and use of acaricides, plus the difference in the genetic component of animals evaluated in both studies.

It is important to remember that the tick $R$. (B.) microplus is commonly called the cattle tick, as it presents a special predilection for animals of Bos

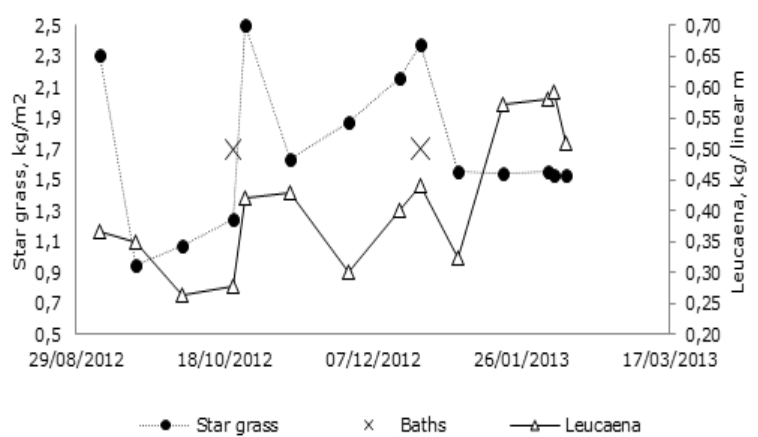

Figure 6. Forage biomass produced in silvopastoral systems and its possible relationship with acaricide baths, Hacienda Lucerna, Bugalagrande, Valle del Cauca.

disminuyo $74.5 \%$ hacia finales de Octubre y $38.8 \%$ posterior al baño realizado en diciembre.

\section{DISCUSIÓN}

La garrapata $R$. (B.) microplus genera grandes pérdidas económicas en la producción ganadera, las cuales están relacionadas con disminución en la producción láctea y cárnica, infecciones por hemoparásitos y un aumento de costos de producción por los baños acaricidas. Los efectos negativos varían en cada animal debido a la posible existencia de resistencia adquirida y natural. La raza del animal, su estado fisiológico y su estado de salud influyen en la susceptibilidad de los animales a las garrapatas (13). La mayor pérdida económica se centra en la disminución de producción láctea, problemas reproductivos y mortalidad. Adicionalmente, existen pérdidas indirectas en los tratamientos para hemoparásitos y en los baños sintéticos para el control de garrapatas (14).

Cargas parasitarias en los grupos de estudio. Los resultados de este estudio son similares a los reportados por Salazar et al (2), en un estudio realizado en el municipio de Piedras, Tolima en el que se observó menor carga parasitaria en bovinos Bos indicus $x$ Bos taurus que pastoreaban en sistemas silvopastoriles en comparación con bovinos del mismo cruce que pastoreaban en praderas en monocultivo. Esto corrobora que existe menor carga de garrapatas en animales pastoreando en sistemas silvopastoriles. Por el contrario, Navas (14), reportó que el número de larvas encontradas en el suelo en potreros con arboles no tuvo diferencias con aquellas encontradas en un potrero sin árboles. Es probable que estas diferencias obedezcan a diferencias en los arreglos de los sistemas evaluados, ya que la densidad de arbustos y arboles en el potrero puede generar un cambio en el ecosistema y afectar el ciclo de vida de los seres vivos que lo habitan. 
taurus breeds, which show greater granulocytic reaction to tick infestations (15), making the Lucerna animals susceptible to this ectoparasite. Likewise, six genes have been identified that provide tick resistance to Gyr $x$ Holstein cattle and are able to offer protection in different seasons (16). Therefore, the animal genetic component affects the impact of tick infestations in a herd, having been reported that Bos taurus cattle and their crosses are less tolerant of ticks and require more intense and costly control programs than Bos indicus cattle (17).

Relationship between some abiotic factors and parasite load of $\boldsymbol{R}$. (B.) microplus. The growth rate of a population of poikilothermic organisms such as ticks depends on thermodynamics, that is, at greater temperatures greater are the possibilities of reproductive success (3). Now, due to global warming, the chances of ticks colonizing new biological niches, as the conditions change. Therefore, the greater the temperature, the greater the ability of these arachnids to migrate to new areas $(3,18)$. However, interaction with other biotic and abiotic factors influence the development of nonparasitic phase of $R$. (B.) microplus.

The altitudinal gradient is the abiotic component most limiting to tick populations (19), since affects the temperature at which the tick grows especially during the non-parasitic phase of its cycle. However, with global warming, the restrictions associated with altitude may soon disappear (20). Another important factor is soil drainage, as flooding can be a limiting factor for the growth of tick populations (18). In the study of Adejinmi (21), it was concluded that female ticks exposed to long periods of immersion in water reduce their reproductive capacity. Most pastures where our study took place had good drainage, so this factor was not important to explain our results.

Rain is important for the survival of ticks. When rainfall is accompanied by temperatures below $14^{\circ} \mathrm{C}$, the ability of ticks to oviposition is altered (22). However, the rain is important for the survival of these ectoparasites, as immediately after precipitation there is increased evapotranspiration which in turn leads to an increase in the relative humidity inside the systems (6), encouraging a suitable microclimate for tick larvae to actively search a host. This important step may not be possible during the dry season (23), because any movement of the larvae with low saturated vapor in the air could lead to desiccation. In this study, high rainfall favored high parasite loads in the group of $\mathrm{La}$ Isabela. Salazar et al (2) they observed a similar
En los animales del presente estudio, se observaron conteos al menos 5 veces más altos que los observados en El Chaco por Salazar et al (2). Esto podría deberse a diferencias en manejo y uso de acaricidas, además de la diferencia en el componente genético de los animales evaluados en ambos estudios.

Es importante recordar que la garrapata $R$. (B.) microplus presenta predilección por el ganado Bos taurus, en la cual se ha demostrado una mayor reacción granulocítica ante una infestación de garrapatas (15), lo que hace al ganado Lucerna susceptible a este ectoparásito. De igual forma, se han identificado seis genes que brindan resistencia a bovinos Gyr x Holstein y que son capaces de ofrecer protección en diferentes estaciones del año (16). Por esta razón, el componente genético afecta el impacto de las infestaciones de garrapatas en un hato, habiéndose reportado que los bovinos Bos taurus y sus cruces son menos tolerantes a las garrapatas y requieren programas de control más intensos y costosos, que los bovinos Bos indicus (17).

Relación entre algunos factores abióticos y la carga parasitaria de $R_{\text {. }}\left(B_{\text {. }}\right)$ microplus. La velocidad de crecimiento de una población de organismos poiquilotermos como las garrapatas, depende de la termodinámica, es decir, a mayores temperaturas, mayores posibilidades tiene el organismo de finalizar su etapa reproductiva (3). Ahora, con el calentamiento global, aumentan las posibilidades de colonizar nuevos nichos biológicos, pues cambian las condiciones microclimáticas. Por esta razón, a mayor temperatura, mayor será la capacidad de estos arácnidos para migrar a nuevos territorios $(3,18)$. No obstante, la interacción con otros factores bióticos y abióticos influyen en el desarrollo de la fase no parasítica de $R$. (B.) microplus.

El gradiente altitudinal es el componente abiótico más limitante para la población de garrapatas (19), pues de este depende la temperatura a la que se ve enfrentada la garrapata especialmente durante la fase no parasítica de su ciclo. Sin embargo, con el calentamiento global, las restricciones asociadas con altitud podrían pronto desaparecer (20). Otro factor importante es la capacidad de drenaje del suelo, la tendencia del terreno a una inundación puede ser un limitante para el crecimiento de las poblaciones parasitarias (18). En el estudio de Adejinmi (21), se concluyó que las garrapatas hembras expuestas a largos periodos de inmersión en agua reducen su capacidad reproductiva y cuando las precipitaciones están acompañadas de temperaturas menores a $14^{\circ} \mathrm{C}$, se altera la capacidad de ovoposición de las garrapatas (22). No obstante, la lluvia es importante para la 
pattern in parasite loads in the rainy season, suggesting that the silvopastoral system can act as a buffer against some climatic variables and in turn, alter the ecology of ticks.

Increased humidity and suitable temperature inside the pasture, leads to a suitable saturation deficit, which is the amount of water needed for air moisture to condense as dew, and is calculated based on temperature and relative humidity. According to Gern et al (18), the saturation deficit is important to ticks for two reasons: 1 ). The larvae take water from the water vapor to avoid desiccation. 2). When water vapor is insufficient, larvae descend from the leaves to fetch water; wasting energy that could be used to survive longer.

The saturation deficit is a value frequently used in modeling the population dynamics of tick populations both to assess climate change, and to simulate the effect of rotational grazing $(24,25)$. From these exercises it is concluded that there is a strong relationship between mortality of larvae and eggs and saturation deficit (25). It is important to note that, after a retrospective study that took weather information from different European countries, it was concluded that there was no relationship between cumulative rain with relative humidity and saturation deficit (26). Thus, it is not appropriate to take precipitation as the only explanatory variable for tick population dynamics (26).

Another of the abiotic factors studied was radiation, which has an important effect on young organisms. Langrová et al (27) conducted a study to assess the influence of the drying effects of UV radiation in intestinal parasites in horses exposed to the sun for several days. The results were $2.5 \%$ death of larvae 3 (infective) after 17 days of exposure (27). Similar work was carried out with Tetranychus urticae, but this time aiming to assess the effect of exposure to UV rays. Brief UV exposure periods lead to larvae death and unviable eggs (28). NavasPanadero (14) evaluated the photosynthetically active radiation and its effect on the number of larvae of ticks found in pastures with different silvopastoral arrangements and found no difference between the silvopastoral and more conventional arrangements. It is important to recognize that UV rays are not a single homogeneous variable, but have different effects according to wavelength (Table 2).

In the present study there was a decrease in tick loads when radiation prior to tick counts was high. This could lead to a decrease of larvae and viable egg numbers in the pastures, thus sobrevivencia de estos ectoparásitos, ya que, luego de la lluvia aumenta la evapotranspiración que a la vez lleva a un incremento en la humedad relativa en el interior de los sistemas (6); propiciando un microclima adecuado a las larvas de garrapata para la búsqueda de un hospedador. Este paso importante no podría ser posible durante época seca (23), debido a que cualquier movimiento de las larvas con bajo nivel de vapor saturante en el aire podría llevar a la desecación. En este estudio, las altas precipitaciones favorecieron las altas cargas parasitarias en el grupo de La Isabela. Salazar et al (2), observaron un patrón similar en cargas parasitarias en época de lluvia, sugiriendo que el sistema silvopastoril puede actuar como amortiguador ante algunos variables climáticas y a su vez alterar la ecología de las garrapatas.

Un aumento en la humedad y una temperatura adecuada en el interior del potrero, resulta en un adecuado déficit de saturación. El déficit de saturación es la cantidad de agua que le falta al aire para condensar en rocío y se calcula con base a la temperatura y la humedad relativa. De acuerdo con Gern et al (18), el déficit de saturación es importante para las garrapatas por dos razones: 1 ) Las larvas toman el agua del vapor de agua y así evitar la desecación. 2) Cuando el vapor de agua es deficiente, las larvas descienden de las hojas a buscar agua; gastando energía que podría usar para sobrevivir más tiempo.

El déficit de saturación, es un valor frecuentemente usado en modelación de la dinámica poblacional de garrapatas, tanto para evaluar poblaciones durante cambios climáticos, como para simular el efecto de la rotación de potreros $(24,25)$. De estas modelaciones se concluye que existe una gran relación entre la mortalidad de larvas y huevos con el déficit de saturación (25). Es importante aclarar, que luego de un estudio retrospectivo en el que tomó información meteorológica de diferentes países europeos, se concluyó que no existía relación entre el acumulado de lluvia con la humedad relativa y el déficit de saturación (26). Así, no es adecuado tomar la precipitación como la única variable explicativa para la dinámica de las garrapatas (26).

Otro de los factores abióticos estudiados es la radiación, la cual tiene un efecto importante sobre los organismos jóvenes. Langrová et al (27) realizó un estudio para evaluar la influencia de la desecación causada por la radiación UV en parásitos intestinales de caballos expuestos al sol por varios días. Los resultados obtenidos fueron la muerte del $2.5 \%$ de las larvas 3 (infectiva) luego de 17 días de exposición (27). Un trabajo similar se realizó con Tetranychus urticae, pero este pretendía evaluar el tiempo de exposición a los rayos UV. Los resultados 
Table 2. Overview of ultraviolet (UV) rays and their biological effects (28).

\begin{tabular}{|c|c|c|}
\hline $\begin{array}{l}\text { Frequency } \\
\text { band }\end{array}$ & $\begin{array}{c}\text { Physical and biological } \\
\text { properties }\end{array}$ & Effect in animals \\
\hline $\begin{array}{c}\text { UV-C } \\
(200-280 \mathrm{~nm})\end{array}$ & $\begin{array}{l}\text { Short wavelength. } \\
\text { Highly energetic and of } \\
\text { easy absorption by nucleic } \\
\text { acids to. }\end{array}$ & None \\
\hline $\begin{array}{c}\text { UV - B } \\
(280-315 \mathrm{~nm})\end{array}$ & $\begin{array}{l}\text { Reach the biosphere. } \\
\text { Absorbed by biological } \\
\text { molecules including nu- } \\
\text { cleic acids }\end{array}$ & $\begin{array}{l}\text { Damage eyes and skin. } \\
\text { Can be acute or chronic. } \\
\text { Compromised immune } \\
\text { system. } \\
\text { Reduced amphibian popu- } \\
\text { lations. } \\
\text { Acute exposure can cause } \\
\text { burns in humans } \\
\text { Chronic exposure is a cau- } \\
\text { se of skin cancer }\end{array}$ \\
\hline $\begin{array}{c}\text { UV-A } \\
(315-400 \mathrm{~nm})\end{array}$ & $\begin{array}{l}\text { Less energetic than UV-B } \\
\text { Present at the highest in- } \\
\text { tensity of sunlight } \\
\text { Absorbed by many pro- } \\
\text { teins, including major } \\
\text { photoreceptors }\end{array}$ & $\begin{array}{l}\text { Increasingly recognized as } \\
\text { an important factor in the } \\
\text { development of skin can- } \\
\text { cer in humans } \\
\text { Widely used in vision of } \\
\text { many invertebrates and } \\
\text { vertebrates }\end{array}$ \\
\hline
\end{tabular}

solar radiation reduce the chances of survival of organisms (29). Future studies should include quantification of different amounts of UV rays reaching the niches occupied by ticks in both ISS and traditional systems.

There is no single variable on which to base a study of tick dynamics, making it difficult to identify one variable as the most important for the biological cycle of the tick R. (B.) microplus.

Silvopastoral systems are beneficial for both for the environment and biodiversity (7) and livestock production (8) due to increased availability and nutritional quality of forage biomass (7) and environmental conditions that reduce climate stress (10). A silvopastoral system could encourage the growth of the population of ticks $R$. (B.) microplus, by generating a more suitable growth habitat. However, more favorable habitat for insects and other arachnids which can act as natural tick predators are also generated, keeping the ecosystem in balance.

In conclusion, when comparing animals of the same physiological state and with a similar level of milk production, animals grazing in ISS have $56 \%$ lower tick load than that observed in a monoculture pasture system. In turn, animals with greater nutritional requirements show greater ticks loads compared with cows of other groups.

Both abiotic and biotic factors influence parasite loads, and it is not possible to identify a single variable on which to base a study of dynamics of $R(B)$ microplus ticks, but there is an evident ecosystem effect on the population of ticks. obtenidos en individuos tratados con poco tiempo de exposición a los rayos UV fueron la muerte de larvas y la inviabilidad de los huevos (28). Navas (14) evaluó la radiación fotosintética activa y su efecto en el número de larvas de garrapatas que se encuentran en potreros con diferentes arreglos silvopastoriles y no encontró diferencias entre el arreglo silvopastoril y el no silvopastoril. Es importante reconocer que los rayos UV no son una variable única y homogénea, sino que tienen diferentes efectos de acuerdo a su longitud de onda (Tabla 2).

En el presente estudio se observó, una disminución en la carga parasitaria cuando días previos al conteo la radiación fue alta. Esto pudo conducir a una disminución de larvas y huevos en los potreros, pues, la radiación solar afecta nichos ecológicos alterando la respuesta de los organismos al medio y disminuyendo su probabilidad de sobrevivencia (29). Futuros estudios deberán incluir la cuantificación de las diferentes cantidades de rayos UV que alcanzan los nichos ocupados por las garrapatas tanto en sistemas silvopastoriles como tradicionales.

No existe una única variable en la que se pueda basar o concluir un estudio de dinámica de garrapatas, lo que dificulta etiquetar a una de ellas como la más importante para el desarrollo del ciclo biológico de la garrapata R. (B.) microplus.

Los sistemas silvopastoriles son benéficos tanto para el medio ambiente y la biodiversidad (7) como para la producción ganadera (8), por la mayor una oferta de biomasa forrajera de mejor calidad nutricional (7) y condiciones ambientales que disminuyen el estrés climático (10). Un sistema silvopastoril podría fomentar el crecimiento de la población de garrapatas $R$. (B.) microplus, por la generación de un hábitat adecuado. Sin embargo, también se generan hábitats favorables para insectos y otros arácnidos que pueden actuar como depredadores naturales de la garrapata, manteniendo el ecosistema en equilibrio.

En conclusión, al comparar animales en el mismo estado fisiológico y con un nivel similar de producción láctea, los animales que pastorean en SSPi tienen $56 \%$ menos carga parasitaria que la observada en un sistema de praderas en monocultivo. A la vez, los individuos con mayor requerimiento nutricional como el grupo de recién paridas muestran mayor carga parasitaria en comparación con las hembras de los demás grupos.

Factores abióticos y bióticos tienen influencia sobre las cargas parasitarias y no se puede afirmar la existencia de una única variable en la que se pueda basar un estudio de dinámica de garrapatas $R$. (B.) microplus, pero si en un efecto del ecosistema sobre la población de garrapatas. 


\section{REFERENCIAS}

1. Rodríguez-Vivas RI, Hodgkinson JE, Trees. Revisión: Resistencia a los acaricidas en Rhipicephalus (Boophilus) microplus: situación actual y mecanismos de resistencia. Rev Mex Cienc Pecu 2012;3 Supl 1:9-24 [fecha de acceso 11 de marzo de 2015]; URL disponible en http://www.tecnicapecuaria.org.mx/ trabajos/201210084933.pdf

2. Salazar Benjumea RS, Barahona Rosales R, Chará Orozco JD, Sánchez Pinzón MS. Productivity and tick load in bos indicus $x b$. taurus cattle in a tropical dry forest silvopastoral system. Tropical and Subtropical Agroecosystems 18(2015):103-112

3. Frazier MR, Huey RB, Berrigan D, Gern L, Morán Cadenas F, Burri C. Thermodynamics constrains the evolution of insect population growth rates: "warmer is better". Am Nat 2006; 168(4):512-20.

4. Estrada-Peña A, Bouattour A, Camicas JL, Guglielmone A, Horak I, Jongejan F, Latif A, Pegram R, Walker AR. The known distribution and ecological preferences of the tick subgenus Boophilus (Acari: Ixodidae) in Africa and Latin America. Exp App Acarol 2006; 38:219-335.

5. Sutherst RW, Bourne AS. The effect of desiccation and low temperature on the viability of eggs and emerging larvae of the tick, Rhipicephalus (Boophilus) microplus (Canestrini) (Ixodidae). Int J Parasitol 2006; 36:193-200

6. Corson, M.S, (2004). Microclimate influence in a physiological model of cattle-fever tick (Boophilus spp.) population dynamics. Ecol Model. 2004; 180:487-514.

7. Cuartas CA, Naranjo JF, Tarazona AM, Murgueitio E, Chará JD, Ku Vera J et al. Contribution of intensive silvopastoral systems to animal performance and to adaptation and mitigation of climate change. Rev Col Cienc Pec. 2014; 27(2):76-94.

8. Murgueitio-Restrepo E, Chará-Orozco JD, Barahona-Rosales R, Cuartas-Cardona CA, Naranjo-Ramírez, JF. Intensive silvopastoral systems (ISPS), mitigation and adaptation tool to climate change. Tropical and Subtropical Agroecosystems 2014; 17(3):501-507.
9. Cuartas CA, Naranjo JF, Tarazona AM, Barahona $R$. Uso de la energía en bovinos pastoreando sistemas silvopastoriles intensivos con Leucaena leucocephala y su relación con el desempeño animal. Rev CES Med Vet Zoot 2013; 8(1):70-81.

10. Tarazona AM, Ceballos MC, Cuartas CA, Naranjo JF, Murgueitio E, Barahona R. The relationship between nutritional status and bovine welfare associated with adoption of intensive silvopastoral systems in tropical conditions. Some Case Studies. Roma: FAO; 2013.

11. Wharton $\mathrm{RH}$, Utech KBW. The relation between engorgement and dropping of Boophilus microplus (Canestrini) (Ixodidae) to the assessment of tick numbers on cattle. J Aust Entomol Soc 1970; 9:171-182.

12. Haydock KP, Shaw NH. The comparative yield method for estimating dry matter yield of pasture. Aust J Exp Agr 1975; (15):663-670.

13. Jonsson NN. The productivity effects of cattle tick (Boophilus microplus) infestation on cattle, with particular reference to Bos indicus cattle and their crosses. Vet Parasitol 2006; 137(1-2):1-10.

14. Navas Panadero A. Influencia de la cobertura arborea de sistemas silvopastoriles en la distribución de garrapatas en fincas ganaderas en el bosque seco tropical. [Tesis M.Sc]. Turrialba, Costa Rica: 2003. URL Disponible en: http://www.sidalc.net/repdoc/A0116e/ A0116e.pdf.

15. Constantinoiu CC, Jackson LA, Jorgensen WK, Lew-Tabor AE, Piper EK, Mayer DG, et al. Local immune response against larvae of Rhipicephalus (Boophilus) microplus in Bos taurus indicus and Bos taurus taurus cattle. Intern J Parasitol 2010; 40(7):865-875.

16. Machado MA, Azevedo, AL, Teodoro RL, Pires MA, Peixoto MG, de Freitas C, Prata MC, Furlong J, et al. Genome wide scan for quantitative trait loci affecting tick resistance in cattle (Bos taurus $\times$ Bos indicus). BMC Genomics 2010; 11:280. [Fecha de acceso 11 de marzo de 2015]; URL disponible en http:// www.biomedcentral.com/content/pdf/14712164-11-280.pdf 
17. Molento MB, Fortes FS, Buzatti A, Kloster FS, Sprenger LK, Coimbra E, et al. Partial selective treatment of Rhipicephalus microplus and breed resistance variation in beef cows in Rio Grande do Sul, Brazil. Vet Parasitol 2013; 192(1):234-239.

18. Gern L, Moran Cadenas F, Burri C. Influence of some climatic factors on Ixodes ricinus ticks studied along altitudinal gradients in two geographic regions in Switzerland. Int J Med Microbial 2008; 298(1):55-59.

19. Cortés Vencino JA, Betancourt JA, Argüelles J, Pulido L A. Distribución de garrapatas Rhipicephalus (Boophilus) microplus en bovinos y fincas del altiplano cundiboyacense (Colombia). CORPOICA Cienc Tecnol Agropecu 2010; 11(1):73-84.

20. Estrada-Peña A, Venzal JM. High-resolution predictive mapping for Boophilus annulatus and B. microplus (Acari: ixodidae) in Mexico and Southern Texas. Vet Parasitol 2006; 142:350-358.

21. Adejinmi JO. Effect of water flooding on the oviposition capacity of engorged adult females and hatchability of eggs of dog ticks: Rhipicephalus sanguineus and Haemaphysalis leachi leachi. J Parasitol Res 2011; 11 Article ID 824162. URL disponible en http://www. hindawi.com/journals/jpr/2011/824162/cta/

22. Süss J, Klaus C, Gerstengarbe FW, Werner PC. What Makes Ticks Tick? Climate Change, Ticks, and Tick-Borne Diseases. J Travel Med 2008; 15(1):39-45.

23. Tomkins JL, Aungier J, Hazel W, Gilbert L. Towards an Evolutionary Understanding of Questing Behaviour in the Tick Ixodes ricinus. PLoS ONE 2014; 9(10):e110028. URL disponible en http://www.plosone.org/article/ fetchObject.action?uri=info: doi/10.1371/ journal.pone. $0110028 \&$ representation $=$ PDF
24. Hoch T, Monnet Y, Agoulon A. Influence of host migration between woodland and pasture on the population dynamics of the tick Ixodes ricinus: A modelling approach. Ecol Model 2010; 221(15):1798-1806.

25. Navas Panadero A. Importancia de los sistemas silvopastoriles en la reducción del estrés calórico en sistemas de producción ganadera tropical. Revista de Medicina Veterinaria 2010; 19:113-122. URL disponible en: http://revistas.lasalle.edu.co/index.php/ mv/article/view/782/691

26. Alonso-Carné J, García-Martín A, EstradaPeña A. Assessing the statistical relationships among water-derived climate variables, rainfall, and remotely sensed features of vegetation: implications for evaluating the habitat of ticks. Exp Appl Acarol 2015; 65(1):107-24.

27. Langrová I, Jankovská I, Vadlejc, J, Libra M, Lytvynets A, Makovcová K. The influence of desiccation and UV radiation on the development and survival of free-living stages of cyathostomins under field and laboratory conditions. Helminthologia 2008; 45(1):32-40.

28. Murata Y, Osakabe M. The Bunsen-Roscoe reciprocity law in ultraviolet-B-induced mortality of the two-spotted spider mite Tetranychus urticae. J Insect Physiol 2013; 59(3):241-247.

29. Paul ND, Gwynn-Jones D. Ecological roles of solar UV radiation: towards an integrated approach. Trends Ecol Evol 2003; 18(1):48-55. 